ОСОБЛИВОСТІ ІМПЛЕМЕНТАЦІЇ ПРИНЦИПУ НАСТУПНОСТІ

МІЖ ДОШКІЛЬНОЮ І ПОЧАТКОВОЮ ОСВІТОЮ

В КОНТЕКСТІ РЕФОРМИ «НОВА УКРАЇНСЬКА ШКОЛА»

\title{
PECULIARITIES OF IMPLEMENTATION OF THE PRINCIPLE OF FOLLOW-UP BETWEEN PRESCHOOL AND PRIMARY EDUCATION IN THE CONTEXT OF THE "NEW UKRAINIAN SCHOOL" REFORM
}

у статmі розкрито особливості реалізації принципу наступності дошкільної та початкової освіти в контексті ресрорми «Нова українська школа». Автор розкриває взаємозв'язки змісту основних складників формули Нової української школи і Базового компонента дошкільно освіти з метою виявлення закономірностей наступності.

Імплементація наступності в освітній процес закладів дошкільної освіти і початкової школи здійснюється на основі компетентнісно зорієнтованого підходу. Формування ключових компетентностей $і$ наскрізних умінь у дітей старшого дошкільного віку й молодших школярів, відповідно до вимог Державного стандарту, відбувається узгоджено й послідовно, що сприяє едрективності імплементації принципу наступності в освітній простір. Реалізація принципу наступності між ланками дошкільної та почат кової освіти зумовлює ефективне фрормування ключових компетентностей і наскрізних умінь відповідно до них. Важливою передумовою фрормування ключових компетентностей $\epsilon$ розвиток особистісних базових якостей дитини. Базові особистісні якості слугують основою опанування здобувачами освіти наскрізних умінь, серед яких на особливу увагу заслуговують «уміння - відповідь часу»: системне мислення, критичне мислення, ініціативність, креативність, уміння співпрацювати з іншими ефективно розв'язувати проблемні завдання. На розвиток ціннісних орієнтацій, формування позитивної мотивації до процесів пізнання спрямовані виховна й розвивальна складові частини як ключові позиції освітнього процесу в закладах дошкільної освіти і початкової школи.

Стандартами передбачається формування здатностей дитини як здобувача освіти через активності - певні види діяльності. На особливу увагу заслуговують такі види рухових активностей, які максимально сприяють творчому розвитку, мають практико-орієнтований характер, максимально моделюють життєві ситуації відповідно до вікових потреб і здатнос тей дітей. Тенденція Нової української школи передбачає спільні узгоджені дії всіх суб'єктів освітнього процесу, управлінців, педагогічних працівників, батьків, з метою створення ефективних умов, спрямованих на особистісний розвиток, навчання, виховання дітей старшого дошкільного віку і молодших школярів. Відпо відно до Кончепції «Нова українська школа», упровадження інфрормаційного трансферу для вихователів закладів дошкільної освіти й учи телів початкової школи у площині обміну досвідом - необхідна умова імплементації принципу наступності в освітній процес.

Наступність між закладами дошкільної освіти і початкової школи уможливлюється через єдність і узгодженість освітньої мети, змісту освітніх ліній, когнітивно-пізнавального освіт нього середовища (форми організації освітнього процесу, технології, методи, прийоми, засоби).

Ключові слова: реформа «Нова українська школа», принцип наступності, початкова школа, дошкільна освіта.
The article reveals the peculiarities of the implementation of the principle of continuity of preschool and primary education in the context of the reform of the "New Ukrainian School". The author reveals the relationship between the content of the main components of the formula of the New Ukrainian School and the Basic component of preschool education in order to identify patterns of continuity.

The implementation of continuity in the educational process of preschool and primary schools is based on a competency-based approach. The formation of key competencies and cross-cutting skills in older preschool children and younger students, in accordance with the requirements of the State Standard, is coordinated and consistent, which contributes to the effectiveness of the implementation of the principle of continuity in the educational process.

Implementation of the principle of continuity in preschool and primary school is possible through the unity and consistency of educational goals, content of educational lines, cognitive-cognitive educational environment (forms of organization of the educational process, technologies, methods, techniques, tools). An important condition for the implementation of the principle of continuity in the educational environmen is the creation of a unified system of interaction and cooperation between managers, teachers, parents; implementation of the practical aspect of cooperation between the preschool and primary school at the level of activities with children. Basic personal qualities are the basis for students to master the cross-cutting skills, among which deserve special attention "skills-response time": systematic thinking, critical thinking, initiative, creativity, ability to cooperate with others, effectively solve problems. Educational and developmental com ponents as key positions of the educational process in preschool and primary school institutions are aimed at the development of value orientations, the formation of positive motivation for the processes of cognition.

Special attention should be paid to such types of motor activities that maximally promote creative development, are practice-oriented in nature, maximally model life situations in accordance with the age needs and abilities of children. The trend of the New Ukrainian School envisages joint coordinated actions of all subjects of the educational process (managers, teachers, parents) in order to create effective conditions aimed at personal development, education, upbringing of older preschool children and younger students. According to the Concept of the New Ukrainian School, the introduction of information transfer for educators of preschool institutions and primary school teachers in the field of exchange of experience is a necessary condition for the implementation of the principle of continuity in the educational process. In the field of "educators-teachers" the introduction of information transfer for educators of preschool education and primary school teachers in order to share experiences is a necessary condition for the implementation of the principle of continuity in the educational process. In the field of "teachers-parents" information and educational work in the trajectory of compliance with the principle of continuity between preschool and primary education contributes to a better understanding of the issue, increasing the level of methodological literacy of parents. Key words: reform "New Ukrainian school", principle of continuity, primary school, preschool education. 
Постановка проблеми в загальному вигляді. Становлення України як демократичної держави в сучасному світі передбачає глобальні зміни у стратегії розвитку, оскільки стрімка зміна економічних, соціально-культурних, екологічних та правових умов потребує корінних змін у всьому державно-громадському житті країни. Докорінні зміни просочують освітню галузь, яка відповідає викликам і потребам часу змінами нормативної бази. Національна стратегія розвитку освіти України до 2021 р. передбачає модернізацію мережі навчальних закладів із метою більш ефективного використання їхніх матеріально-технічних, кадрових, фрінансових, управлінських ресурсів для забезпечення доступності та якості освіти.

Важливим залишається питання забезпечення неперервності й наступності у процесі здобуття людиною якісної освіти. У процесі створення єдиного освітнього простору проблема реалізації на практиці принципу наступності між суміжними ланками освіти, зокрема дошкільною і початковою, у контексті реформи «Нова українська школа» $\epsilon$ своєчасною й актуальною.

Аналіз останніх досліджень і публікацій. Здійснення неперервності в освіті цілком залежить від можливості реалізувати принцип наступності між суміжними ланками освіти. Проблематику наступності в освіті досліджували педагоги-класики (А. Дістервег, Я. Коменський, Й. Песталоцці). Педагогічна спадщина В. Сухомлинського відображає думку стосовно заборони на внесення різких змін у життя дітей. Натомість зміни, нове в житті повинні з'являтися поступово і не приголомшувати лавиною вражень [4]. На сучасному етапі педагогічних досліджень десрініцію «наступність в освіті» більшість науковців визначають як дидактичний принцип, що спрямовує логіку освітнього процесу і забезпечує його ефективність (А. Богуш, Л. Кравчук, Т. Рожок). Однак питання реалізації принципу наступності між дошкільною і початковою освітою в контексті реформи «Нова українська школа» потребує ґрунтовного висвітлення.

Мета статті - обґрунтувати особливості імплементації принципу наступності дошкільної та початкової освіти в контексті ресорми «Нова українська школа» в освітній процес.

Виклад основного матеріалу. Реформування загальної середньої освіти на період до 2029 р. відбувається відповідно до Концепції «Нова українська школа». Ключовими складниками фрормули Нової української школи визначено: педагогіку партнерства (активну взаємодію суб'єктів освітнього процесу: педагога, дитини, батьків; взаємозв'язки між суб'єктами доцільно будувати на взаємодовірі, партнерстві); побудову взаємин у площині трикутника «педагог - учень - батьки» на засадах гуманізму й поваги, визнання будьякої особистості як найвищої цінності; оновлений зміст освіти, що спрямований на кінцевий результат - набуття життєвих компетентностей і успішну самореалізацію здобувача освіти в суспільстві; компетентнісно зорієнтоване планування змісту освіти; орієнтація на потреби дитини з урахуванням її вподобань, здібностей, здатностей із метою максимального розкриття особистості як суспільно значущої одиниці; переосмислення значущості дефініції «навчально-виховний процес», де «навчальний» визначалося зі знаком «більше» на «освітній процес», у якому рівноправне важливе місце посідає «виховний процес» (провідна роль виховання, орієнтація змісту освіти на моральні цінності та якості особистості); створення сучасного освітнього творчого середовища [3], у якому оновлений зміст освіти реалізується сучасними методами, засобами, технологіями.

Сучасну тенденцію розвитку дошкільної та початкової освіти в умовах реформування загальної середньої освіти детально прописано в Базовому компоненті дошкільної освіти (2012р.) та Державному стандарті початкової освіти (2018р.) [1]. Компетентнісно зорієнтований підхід наскрізно проходить у зазначених документах через визначення ключових компетентностей. Базовий компонент дошкільної освіти окреслює ключові компетентності, що закладаються в дошкільному віці: мовленнєву, здоров'язбережувальну, природничоекологічну, комунікативну, соціальну, особистіснооцінну предметно-практичної, ігрову, сенсорнопізнавальну, художньо-продуктивну. На основі зазначених фрормуються ключові компетентності, визначені Державним стандартом початкової освіти, а саме: вільне володіння державною мовою, здатність спілкуватися рідною й іноземними мовами; культурна, громадянські та соціальні компетентності; математична компетентність, компетентності в галузі природничих наук, техніки та технологій; екологічна, інформаційнокомунікаційна, інноваційність, підприємливість та фрінансова грамотність; навчання впродовж життя.

Важливо зазначити, що стандартами передбачається формування здатностей дитини як здобувача освіти через активності - певні види діяльності. Активності дитини дошкільного віку (спілкування, гра, рухова, пізнавальна, господарсько-побутова, художньо-естетична) спрямовані на логічну підготовку і поступовий перехід до провідного виду діяльності - навчання в початкових класах. За збереження наступності в питанні активностей і провідної діяльності дитини концепцією Нової української школи передбачено в 1-2 класах створення адаптаційно-ігрового періоду, який спрямований на поступовий психологічно адаптований перехід дитини від ігри до навчання. Другий цикл - 3-4 класи - основний.

Основою фрормування здатностей, активностей, відповідно до Державного стандарту освіти, 
визначені необхідні базові якості особистості дитини. Базові особистісні якості (уважність, спостережливість, ініціативність, допитливість, самостійність, чуйність, відповідальність, охайність тощо) закладаються в дітей старшого дошкільного віку, стають базою для подальшого розвитку і вдосконалення особистості у школі, а також основою опанування здобувачами освіти наскрізних умінь, серед яких на особливу увагу заслуговують «уміння - відповідь часу»: системне мислення, критичне мислення, ініціативність, креативність, уміння співпрацювати 3 іншими, ефективно розв'язувати проблемні завдання, логічно обґрунтовувати власну думку й дії.

Умова єдності й узгодженості змістових освітніх ліній дошкільної та початкової освіти реалізується перехресною обізнаністю вчителів початкових класів / вихователів старших груп з освітніми програмами та технологіями дошкільного закладу освіти / початкової школи. Поступовість і послідовність реалізації чинних освітніх програм, урахування індивідуальних особливостей дитини, ії рівня розвитку на даному етапі, перехресна обізнаність педагогів з освітніми програмами суміжних ланок сприяють органічному збагаченню особистісного розвитку і становленню особистості дитини. Відповідно до основних ідей концепції Нової української школи, основний педагогічний акцент повинен припадати на виховний та розвивальний компоненти освітнього процесу. Прискорене інтенсивне навчання дітей у дошкільних закладах освіти з метою ретельної підготовки до школи, навіть за вимогою батьків, може мати глибокі негативні наслідки інтелектуального перенавантаження і втрати зацікавленості до пізнання. Обов'язкове врахування такого застереження дозволить уникнути дублювання змісту освітніх програм дошкільної та початкової ланок освіти. Ключову позицію в закладах дошкільної освіти повинні посідати виховна й розвивальна складові частини освітнього процесу, спрямовані на соціалізацію дитини, розвиток ціннісних орієнтацій, формування позитивної мотивації до процесів пізнання. Такий підхід не передбачає штучого уповільнення індивідуального темпу розвитку дитини.

3 метою наближення до концептуальних змін у фрорматі Нової української школи доцільно організувати освітній процес дошкільного закладу освіти з урахуванням індивідуальних особливостей, запитів дитини, з орієнтацією на зону найближчого розвитку. Освітня програма «Впевнений старт», розроблена у 2017 р. відповідно до Плану пріоритетних дій Уряду України, відповідає вимогам Базового компонента дошкільної освіти як державного освітнього стандарту [2]. Програма «Впевнений старт» максимально адаптована до сучасних тенденцій, $є$ ефективною платформою для реалізації принципу наступності між закла- дами дошкільної освіти та початковою школою. Зазначена освітня програма відображає комплексний підхід до процесу фрормування особистості дитини та її досягнень. Зазначимо, що освітніми завданнями визначені такі: спрямованість на цілісний розвиток особистості дитини, розкриття творчих здатностей, діяльнісну самореалізацію. Рекомендаціями до впровадження освітньої програми «Впевнений старт» передбачено синтез класичних і сучасних підходів, методів, засобів. Важливе місце в освітній програмі належить діяльнісному підходу з урахуванням провідних видів діяльності дітей старшого дошкільного віку: ігрової, комунікативної, рухової, пізнавальної, господарсько-побутової, художньо-естетичної, а також вікових особливостей.

Забезпеченню сучасної та зручної системи педагогічного процесу в дошкільних закладах і початковій школі сприяють органічне оновлення фрорм організації освітнього процесу: уникнення статичності на заняттях / уроках, відмова від домінування фрронтальних фрорм. Доцільна зміна видів навчально-виховної діяльності, забезпечення оптимальної рухової активності дітей на заняттях / уроках сприятимуть удосконаленню освітнього процесу. Необхідно звернути увагу на такі види рухових активностей, які максимально сприяють творчому розвитку, мають практикоорієнтований характер, максимально моделюють життєві ситуації відповідно до вікових потреб і здатностей дітей. Насичення освітнього простору змодельованими практико-орієнтованими ситуаціями, наближеними до реального життя, не тільки сприяє потребам дітей, але й фрормує в них почуття власної відповідальності за наслідки дій, думок, слів, активізує пізнавальні інтереси, сприяє підвищенню позитивної мотивації до процесу пізнання, фрормує ціннісні орієнтації. Отже, узгодження змісту, форми заняття з доцільними активностями дітей сприяє створенню когнітивнотворчого освітнього середовища у групі / класі.

В освітньому процесі закладну дошкільної освіти та початкової школи діапазон дидактичних методів і прийомів розширюється розвивальними вправами, ігровими технологіями, проблемними пошуковими завданнями, систематичними спостереженнями. Методично грамотно впроваджена організація систематичних спостережень, пошуково-дослідної діяльності в умовах когнітивнотворчого освітнього середовища групи / класу сприяє можливості реалізації принципу перспективності, створює підґрунтя для розвитку важливих особистісних якостей і здатностей до творчої діяльності на майбутнє.

Важливою умовою реалізації принципу наступності в освітньому середовищі між закладами дошкільної освіти та початковою школою є створення єдиної системи взаємодії та співпраці 
між управлінцями, педагогічними працівниками, батьками. Конструктивна тенденція Нової української школи передбачає спільні узгоджені дії цих суб'єктів освітнього процесу з метою створення ефективних умов, спрямованих на особистісний розвиток, навчання, виховання дітей старшого дошкільного віку й молодших школярів. Відповідно до Концепції «Нова українська школа», упровадження інорормаційного трансореру для вихователів закладів дошкільної освіти й учителів початкової школи у площині обміну досвідом (щодо застосування фрорм організації освітнього процесу, технологій, методів і засобів, ефективних у створенні у групі (класі) когнітивно-творчого освітнього середовища), визнано необхідною умовою імплементації принципу наступності в освітній процес.

Для вихователів закладів дошкільної освіти й учителів початкової школи методична робота щодо забезпечення наступності дошкільної і початкової освіти може здійснюватися такими заходами: плануванням, підготовкою і проведенням спільних інформаційно-просвітницьких і методичних заходів (педагогічні ради, онлайн вебінари, семінари-практикуми, кругли столи, науково-практичні конфреренції, онлайн-конференції, консультаційні диспути, тематичні виставки, відеолекторії, тренінги); організацією перехресних взаємовідвідувань учителями / вихователями відкритих занять із дітьми старшого дошкільного віку / уроків і позааудиторних занять у початковій школі; науковопедагогічними дослідженнями (анкетування, тестування, опитування) педагогічних працівників із подальшою статистичною обробкою отриманих даних, ранжуванням результатів, офрормленням висновків у формі методичних рекомендацій, тез, наукових статей; створенням спільних робочих, творчих груп для обговорення актуальних питань, розгляду проблемних ситуацій, розробленням методичних рекомендацій і порад, участі у спільних творчо-пошукових проєктах.

У площині «педагоги - батьки» інсрормаційнопросвітницька робота у траєкторії дотримання принципу наступності між дошкільною та початковою освітою сприяє кращому розумінню проблематики, підвищенню рівня методичної грамотності батьків. Робота $з$ батьками передбачає заходи, що сприяють ознайомленню із психологічними закономірностями розвитку дітей старшого дошкільного та молодшого шкільного віку, розумінню механізмів соціалізації дитини, а саме: проведення онлайн-тренінгів і вебінарів для батьків; залучення до участі у «Форумах для батьків»; проведення інтернет-консультацій; проведення відеолекторіїв із питань інклюзивної освіти для батьків; проведення анкетувань і опитувань батьків із метою надання індивідуальної консультативної допомоги; проведення «Днів відкритих дверей» у початковій школі.

Висновки. Важливою умовою імплементації принципу наступності дошкільної та початкової освіти в контексті рефрорми «Нова українська школа» в освітній процес $є$ узгодженість освітньої мети, змісту освітніх ліній, створення когнітивнопізнавального освітнього середовища (застосування ефективних фрорм організації освітнього процесу, технологій, методів, прийомів, засобів) з урахуванням вікових та індивідуальних особливостей дітей.

\section{БІБЛІОГРАФІЧНИЙ СПИСОК:}

1. Базовий компонент дошкільної освіти / А. Богуш та ін. Київ, 2012. 26 с.

2. Освітня програма «Впевнений старт» для дітей старшого дошкільного віку / Н. Гавриш та ін. Київ : Українська академія дитинства, 2017. 80 с.

3. Фесенко О. Створення інтелектуально-творчого освітнього середовища як педагогічна умова формування методичної компетентності майбутнього вчителя. Педагогічні науки : збірник наукових праць. Херсон : Херсонський державний університет, 2017. Вип. LXXVII. T. 2. С. 127-131.

4. Черкасов В. Предмет і сутність науки як сорери людської діяльності. Науковий вісник Льотної академії : збірник наукових праць. Серія «Педагогічні науки». Кропивницький : КЛА, 2017. Вип. 1. C. $231-238$. 